\title{
Subconjunctival hemorrhage in Henoch-Schonlein purpura: a case report and literature review
}

\section{Henoch-Schonlein purpurada subkonjonktival hemoraji: olgu sunumu ve literatür taraması}

\author{
Yaprak Akbulut $^{1 *}$ (D), Nesrin Büyüktortop ${ }^{1}$ (D) Cihat Şanlı $^{2}$ (D), Erhan Yumuşak ${ }^{1}$ (D) Tevfik Oğurel $^{1}$ \\ ${ }^{1}$ Kırıkkale University, School of Medicine, Department of Ophthalmology, Kırıkkale, Turkey \\ ${ }^{2}$ Kırıkkale University, School of Medicine, Department of Pediatrics, Kırıkkale, Turkey \\ * Corresponding author: Yaprak Akbulut E-mail: yprk_akblt@hotmail.com ORCID: 0000-0002-7774-2681 \\ Received: 13 August 2018 Accepted: 30 November 2018
}

\begin{abstract}
We report a 5-year-old boy who presented with diffuse abdominal pain, non-thrombocytopenic purpuric skin rash, and bilateral multiple foci of subconjunctival hemorrhage in the inferior bulbar conjunctiva. The patient was diagnosed clinically with Henoch-Schonlein purpura (HSP), according to EULAR/PRINTO/PRES criteria. HSP is a leukocytoclastic small vessel vasculitis. Ocular involvement is very rare. Episcleritis, keratitis, uveitis, cystoid macular edema and cotton wool spots, central retinal artery occlusion, anterior ischemic optic neuropathy and subperiosteal hematoma were reported previously. Here, we present a case of bilateral subconjunctival hemorrhage in a child with HSP for the first time in the English literature.
\end{abstract}

Keywords: Henoch-Schonlein purpura, ocular, subconjunctival hemorrhage, vasculitis

\section{öz}

Bu yazıda diffüz abdominal ağrı, trombositopenik olmayan purpurik deri döküntüsü ve inferior bulbar konjunktivada bilateral multipl subkonjonktival hemoraji ile başvuran 5 yaşında bir erkek hasta sunuldu. Hastaya EULAR / PRINTO / PRES kriterlerine göre klinik olarak Henoch-Schonlein purpurası (HSP) ile tanısı konuldu. HSP bir lökositoklastik küçük damar vaskülitidir. Oküler tutulum çok nadirdir. Episklerit, keratit, üveit, kistoid maküla ödemi ve atılmış pamuk görünümü, santral retinal arter tıkanıkığı, ön iskemik optik nöropati ve subperiosteal hematom daha önce bildirilmiştir. Burada, İngilizce literatürde ilk kez HSP'li bir çocukta bilateral subkonjonktival hemoraji olgusunu sunuyoruz.

Anahtar kelimeler: Henoch-Schonlein purpura, oküler, subkonjonktival hemoraji, vaskülit 


\section{INTRODUCTION}

Henoch-Schonlein purpura (HSP) is an acute immunoglobulin (IG)-A-mediated systemic leukocytoclastic vasculitis characterized by the involvement of small vessels of the skin, gastrointestinal system, kidneys, joints, and rarely the lungs and central nervous system. It is the most common type of vasculitis of childhood. ${ }^{1}$ Diagnosis is based on the presence of non-thrombocytopenic palpable purpura (mandatory criteria), and one or more of the following: diffuse abdominal pain, histopathologic proof of leukococytoclastic vasculitis or proliferative glomerulonephritis with predominant lgA deposits, arthritis or arthralgia, and findings of renal involvement. ${ }^{2}$ Genetic, environmental, and antigenic factors play a role in the etiology of HSP. Most patients report a preceding respiratory tract infection. It is thought that infectious agents may trigger a dysregulated immune response that results in inflammation and vasculitis [2]. Prognosis is generally good

Table 1. Literature review of patients with Henoch-Schonlein purpura and ocular involvement

\begin{tabular}{|c|c|c|}
\hline Reference & $\begin{array}{c}\text { Age, } \\
\text { year/ sex }\end{array}$ & Ocular involvement \\
\hline Ryder, 1976 & $6 / M$ & $\begin{array}{c}\text { Transient conjugate eye deviation and } \\
\text { cortical blindness }\end{array}$ \\
\hline Lorentz, 1980 & $14 / \mathrm{F}$ & Episcleritis \\
\hline Yamabe, 1988 & $63 / M$ & Anterior uveitis, keratitis \\
\hline Ma'luf, 2002 & $5 / M$ & Bilateral subperiosteal orbital hematoma \\
\hline Wu, 2002 & $6 / \mathrm{F}$ & Bilateral central retinal artery occlusion \\
\hline Chuah, 2005 & $54 / \mathrm{M}$ & Anterior ischemic optic neuropathy \\
\hline Muqit, 2005 & $42 / M$ & $\begin{array}{c}\text { Keratitis and bilateral granulomatous anterior } \\
\text { uveitis }\end{array}$ \\
\hline Erer, 2010 & 39/M & Uveitis \\
\hline Ergul, 2010* & $12 / \mathrm{F}$ & $\begin{array}{c}\text { Unilateral generalized subconjunctival } \\
\text { hemorrhage }\end{array}$ \\
\hline Kaur, 2012 & $11 / M$ & Bilateral uveitis \\
\hline Nicholson 2013 & $24 / M$ & $\begin{array}{c}\text { Cystoid macular edema, retinal hemorrhages } \\
\text { and cotton wool spots }\end{array}$ \\
\hline Patheja, 2015 & $21 / M$ & $\begin{array}{l}\text { Cystoid macular edema, retinal hemorrhages } \\
\text { and cotton wool spots }\end{array}$ \\
\hline Present case & $5 / M$ & $\begin{array}{l}\text { Bilateral multiple foci of subconjunctival } \\
\text { hemorrhage }\end{array}$ \\
\hline
\end{tabular}

F: female, M: male, *: Not indexed in pubmed or embase

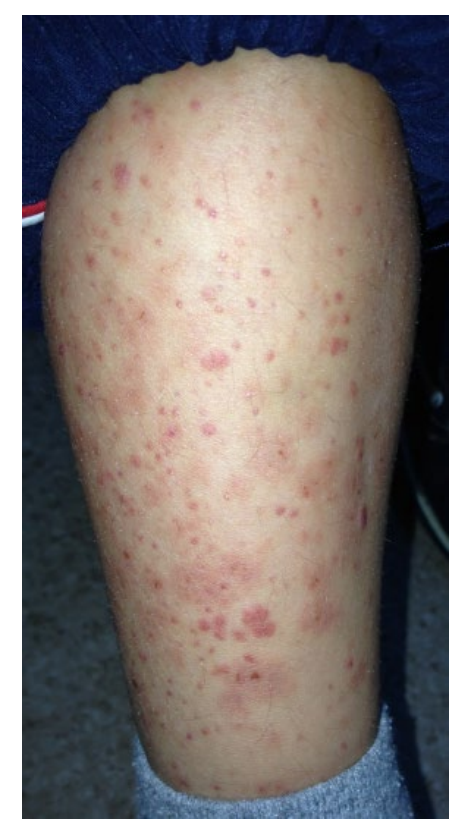

Figure 1. Purpuric skin rash mainly on the lower extremities

and symptomatic treatment is usually sufficient. Corticosteroids may be given to decrease the severity of abdominal pain and arthralgia. Immunomodulatory agents are used with severe nephritis [1].

Ocular involvement in HSP is very rare (Table 1). In this report, we present an unusual case of HSP associated with bilateral multiple foci of subconjunctival hemorrhage $(\mathrm{SCH})$.

\section{CASE REPORT}

A 5-year-old boy was admitted to the Department of Pediatric Emergency, with diffuse abdominal pain and was suspected of having acute abdomen. The parents reported a history of recent pharyngeal infection. On physical examination, there was a purpuric skin rash mainly on the gluteal region and the lower extremities (Figure 1). Intestinal sounds were normoactive. There was no rebound or guarding on the abdominal examination or nausea or vomiting. Extremities and joints were normal with no swelling or tenderness. There was subconjunctival hemorrhage on both eyes. Other physical examination findings were normal. Blood pressure was $110 / 70 \mathrm{mmHg}$ (\%92 percentile). Complete blood count, urine analysis, erythrocyte sedimentation rate, and the bleeding profile were within normal limits. Ultrasonography revealed that the appendix was normal in shape and contour. The fecal occult test was positive. Serum complement C3, C4, perinuclear anti-neutrophil cytoplasmic antibodies ( $P$ ANCA), cytoplasmic antineutrophil cytoplasmic antibodies (C-ANCA), and Ig A levels were within normal limits. Our patient was clinically diagnosed as having HSP according to the European League against Rheumatism/Paediatric 


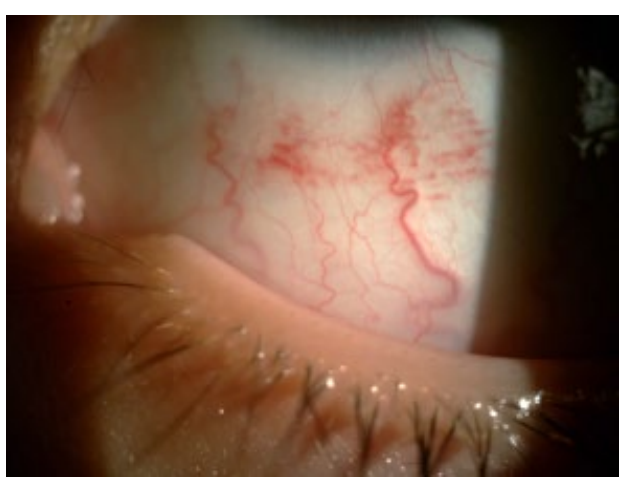

Figure 2. Multiple foci of $\mathrm{SCH}$ in the inferior bulbar conjunctiva of left eye

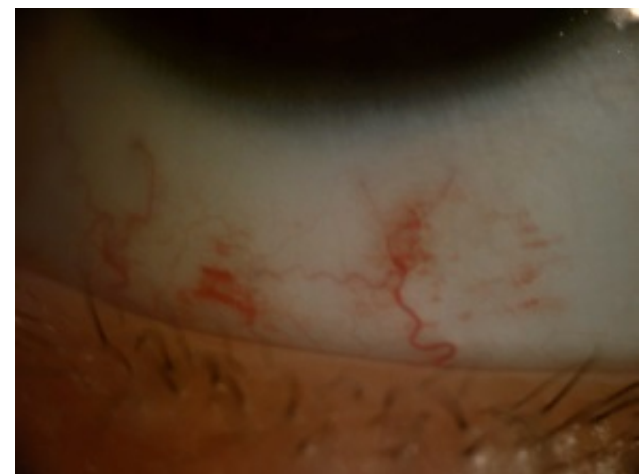

Figure 3. Multiple foci of $\mathrm{SCH}$ in the inferior bulbar conjunctiva of right eye

Rheumatology International Trials Organisation/Paediatric Rheumatology European Society (EULAR/PRINTO/PRES) criteria due to the presence of the typical nonthrombocytopenic purpuric skin rash and gastrointestinal involvement. The patient was referred to ophthalmology because of the unusual SCH. Visual acuity was 20/20 in both eyes. Intraocular pressure was $11 / 11 \mathrm{mmHg}$. Periocular area and eyelids were normal in color and shape. There was no discharge, edema, papillary or follicular reaction. There were multiple foci of $\mathrm{SCH}$ in the inferior bulbar conjunctiva of both eyes (Figure 2 and 3). There were no other abnormalities in the anterior or posterior segment examinations. Intravenous $1 \mathrm{mg} / \mathrm{kg} /$ day prednisone was administered due to severe abdominal pain, which was relieved on the third day of treatment. The skin rash resolved within a month and the $\mathrm{SCH}$ s resolved within 2 weeks. A year later, the patient had a recurrence of purple skin rash on the dorsal side of the feet and the distal part of the legs, again with a history of pharyngeal infection. However, there was no abdominal pain or arthralgia or ocular involvement. Laboratory tests were normal. There was no proteinuria or occult blood in the feces. The patient was followed up for 3 years with no further recurrence. The informed consent was received from the family.

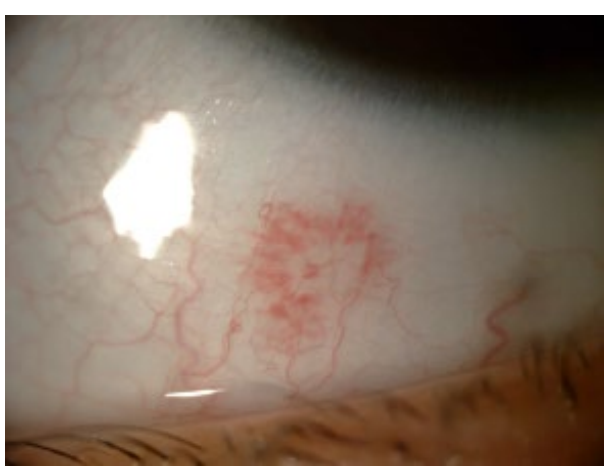

Figure 4. Multiple foci of $\mathrm{SCH}$ cumulating around the end of visible conjunctival vessels

\section{DISCUSSION}

HSP is a form of leukocytoclastic vasculitis in which small superficial vessels of the skin are primarily affected. Immunofluorescence studies showed that $\lg \mathrm{A}, \mathrm{C} 3$, and fibrin were deposited within the walls of involved skin vessels, and in the endothelial and mesangial cells of the kidney [1].

HSP rarely involves the eye. A literature review of ocular manifestations in HSP is summarized in Table 1. The most encountered ocular involvement was uveitis $(n=4)$ [3-6], keratitis accompanied in two of these cases $[3,4]$. There are 2 cases of bilateral cystoid macular edema and cotton wool spots associated with decompensated HSP-related nephropathy $[7,8]$. The other possible vasculitis-related ocular manifestations in HSP were central retinal artery occlusion, subperiosteal hematoma, episcleritis and anterior ischemic optic neuropathy [9-13].

In HSP, the vessel walls are infiltrated by neutrophil granulocytes, and eventually become necrotic. The extravasation of erythrocytes through necrotic vessel walls to the surrounding dermis causes the purpuric skin rash [1]. In our case, we suggest that the conjunctival vascular endothelial cells may also have been affected by the immune complex-mediated immune response. Similar to the skin involvement, the extravasation of erythrocytes through damaged conjunctival vessels might have caused the appearance of $\mathrm{SCH}$. SCH is an acute and non-painful hemorrhage between the conjunctiva and episclera in the absence of discharge and inflammation. It may vary from dot-blot hemorrhages to extensive areas of bleeding. Trauma, systemic vascular disease, sudden severe venous congestion, blood dyscrasias, anticoagulants, acute hemorrhagic conjunctivitis, and conjunctival tumours among others may cause SCH [15]. In our case, there was no history of trauma, hypertension, diabetes, thrombocytopenia, or any sign of ocular inflammation. Also, the presentation of $\mathrm{SCH}$ was atypical because it was not in a 
single circumscribed localization, instead there were multiple foci of SCH cumulating around the end of visible conjunctival vessels (Figure 4).

The lack of risk factors, the bilateral and atypical presentation of hemorrhage, and the concurrent HSP symptoms suggest that SCH might be associated with HSP. However, a conjunctiva biopsy could not be obtained to prove vasculitic involvement. Systemic vasculitides have certain ocular manifestations. SCH is a known manifestation of Kawasaki disease, but it is not common among other pediatric vasculitides [15]. To our knowledge, there is no previous report of SCH associated with HSP in the English literature. HSP may cause severe ocular problems, especially in the presence of nephropathy. It would be better to consider an ophthalmologic consultation in the evaluation of patients with HSP. One of the accompanying ocular findings may be $\mathrm{SCH}$. Accordingly, it would be better to keep $\mathrm{HSP}$ in mind in the differential diagnosis of $\mathrm{SCH}$ in childhood.

\section{LITERATURE SEARCH}

PubMed and EMBASE were searched without date restriction in August 2018 for English-language results using the following terms: Henoch-Schonlein purpura, HenochSchonlein's vasculitis, IgA vasculitis, ocular, ophthalmological, eye.

\section{DECLARATION OF CONFLICT OF INTEREST}

The authors declare no conflict of interest. There is no financial assistance.

\section{REFERENCES}

1. Hetland LE, Susrud KS, Lindahl KH, Bygum A. HenochSchönlein purpura: a literature review. Acta Derm Venereol 2017; 97: 1160-6.

2. Ozen S, Pistorio A, lusan International Trials Organisation (PRINTO). EULAR/PRINTO/PRES criteria for HenochSchönlein purpura, childhood polyarteritis nodosa, childhood Wegener granulomatosis SM, et al. Paediatric Rheumatology and childhood Takayasu arteritis: Ankara 2008. Part II: Final classification criteria. Ann Rheum Dis 2010; 69: 798-806.

3. Yamabe H, Ozawa K, Fukushi K, Kubota $H$, Ohsawa $H$, Akitsu H. IgA nephropathy and Henoch-Schönlein purpura nephritis with anterior uveitis. Nephron 1988; 50: 368-70.
4. Muqit MM, Gallagher MJ, Gavin M, Roberts F, Jardine AG. Henoch-Schonlein purpura with keratitis and granulomatous anterior uveitis. Br J Ophthalmol 2005; 89: 1221-2.

5. Erer B, Kamali S, Cingu K, et al. Recurrent anterior uveitis in Henoch Schonlein's vasculitis. Rheumatol Int 2010; 30: 1377-79.

6. Kaur S, Maheshwari A, Aneja S, et al. Henoch-Schönlein purpura with uveitis: an unusual case and review of literature. Rheumatol Int. 2012; 32: 4057-9.

7. Nicholson L, Mathews D. Bilateral cystoid macular oedema and cotton wool spots associated with HenochSchonlein purpura. BMJ Case Rep 2013; 9: 200159.

8. Patheja RS, Chidgey A. A rare case of bilateral cystoid macular oedema associated with decompensated Henoch-Schonlein purpura-related nephropathy. Clin Exp Ophthalmol 2016; 44: 209-12.

9. Wu TT, Sheu SJ, Chou LC, Wu TT, Sheu SJ, Sheu SJ. Henoch-Schonlein purpura with bilateral central retinal artery occlusion. Br J Ophthalmol 2002; 86: 351-2.

10. Ma'luf RN, Zein WM, El Dairi MA, Bashshur ZF.Bilateral subperiosteal orbital hematomas and Henoch-Schönlein purpura. Arch Ophthalmol 2002; 120: 1398-9.

11. Chuah J, Meaney T. Anterior ischaemic optic neuropathy secondary to Henoch-Schönlein purpura. Eye (Lond) 2005; 19: 1028.

12. Lorentz WB Jr, Weaver RG. Eye involvement in anaphylactoid purpura. Am J Dis Child 1980; 134: 524525.

13. Ryder HG, Marcus O. Henoch-Schönlein purpura: a case report. S Afr Med J 1976; 50: 2005-6.

14. Tarlan B, Kiratli H. Subconjunctival hemorrhage: risk factors and potential indicators. Clin Ophthalmol 2013; 7: 1163-70.

15. Weiss PF. Pediatric vasculitis. Pediatr Clin North Am 2012; 59: 407-23. 